\title{
Rainfall-triggered landslides in the Lisbon region over 2006 and relationships with the North Atlantic Oscillation
}

\author{
J. L. Zêzere ${ }^{1}$, R. M. Trigo ${ }^{2,3}$, M. Fragoso ${ }^{1}$, S. C. Oliveira ${ }^{1}$, and R. A. C. Garcia $^{1}$ \\ ${ }^{1}$ Centro de Estudos Geográficos, Universidade de Lisboa, Portugal \\ ${ }^{2}$ CGUL, IDL, Faculdade de Ciências, Universidade de Lisboa, Portugal \\ ${ }^{3}$ Departamento de Engenharias e Ciências Naturais, Universidade Lusófona, Portugal \\ Received: 3 January 2008 - Revised: 7 May 2008 - Accepted: 7 May 2008 - Published: 15 May 2008
}

\begin{abstract}
Landslides occurred in the Lisbon area during the last 50 years were almost always induced by rainfall and have been used to establish rainfall thresholds for regional landslide activity. In 2006, three new rainfall-triggered landslide events occurred in the study area, namely on the 20 March, the 25-27 October, and the 28 November. Landslide events occurred in March and October 2006 include shallow translational slides and few debris flows, and the corresponding absolute antecedent rainfall was found to be above the threshold for durations ranging from 4 to 10 days. These events also fit the combined threshold of daily precipitation and 5 days calibrated antecedent rainfall values. Likewise the landslide event that took place in late November 2006 includes some slope movements with deeper slip surfaces, when compared with landslides dating from March and October. Moreover, the corresponding absolute antecedent rainfall was also found to be above the 40-day period rainfall threshold.

Here we characterize in detail the short and long-term atmospheric circulation conditions that were responsible for the intense rainfall episodes that have triggered the corresponding landslide events. It is shown that the three rainfall episodes correspond to considerably different synoptic atmospheric patterns, with the March episode being associated to an intense cut-off low system while the October and November episodes appear to be related to more typical Atlantic low pressure systems (and associated fronts) travelling eastwards.

Finally, we analyse the role played by the North Atlantic Oscillation (NAO) during those months marked by landslide activity. It is shown that the NAO index was consistently negative (usually associated with above average precipitation) for the months prior to the landslide events, i.e. between Oc-
\end{abstract}

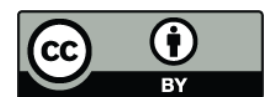

Correspondence to: J. L. Zêzere (jlzezere@ fl.ul.pt) tober 2005 and March 2006, and again between August and October 2006.

\section{Introduction}

High intensity rainfall episodes and long lasting rainfall episodes are recognized as major landslide triggering factors worldwide (Wieckzorek, 1996; Corominas, 2001; Guzzetti et al., 2007). The definition of rainfall amount/duration critical values for slope instability has been attempted for more than 25 years (e.g. Caine, 1980; Fukuoka, 1980; Crozier, 1986). These efforts have been performed in the framework of both "pure" and "applied" research mostly carried out with the aim of landslide risk mitigation (e.g. Keefer et al., 1987; D'Orsi et al., 1997; Aleotti, 2004).

Nevertheless, despite the large amount of work done with this goal (e.g. Van Asch et al., 1999; Corominas, 2001; Polemio and Petrucci, 2000; Zêzere et al., 2005; Guzzetti et al., 2007; among others), it is now recognised that there is no general "universal rule" regarding rainfall thresholds related with slope instability. Additionally, within a single region, different types of slope movements are usually related with distinct hydrological triggering conditions that may be produced by different rainfall episodes (Van Asch et al., 1999; Polemio and Petrucci, 2000; Zêzere, 2000; Corominas, 2001; Zêzere and Rodrigues, 2002; Trigo et al., 2005).

In a recent paper, Guzzetti et al. (2007) summarizes types and characteristics of rainfall thresholds that may be obtained by process-based models, and by empirically based models. Empirical models are supported by the historical record of landslides as well as by the statistical treatment of rainfall data, and can take into account both the event rainfall and the rainfall antecedent conditions. Such statistically-based

Published by Copernicus Publications on behalf of the European Geosciences Union. 


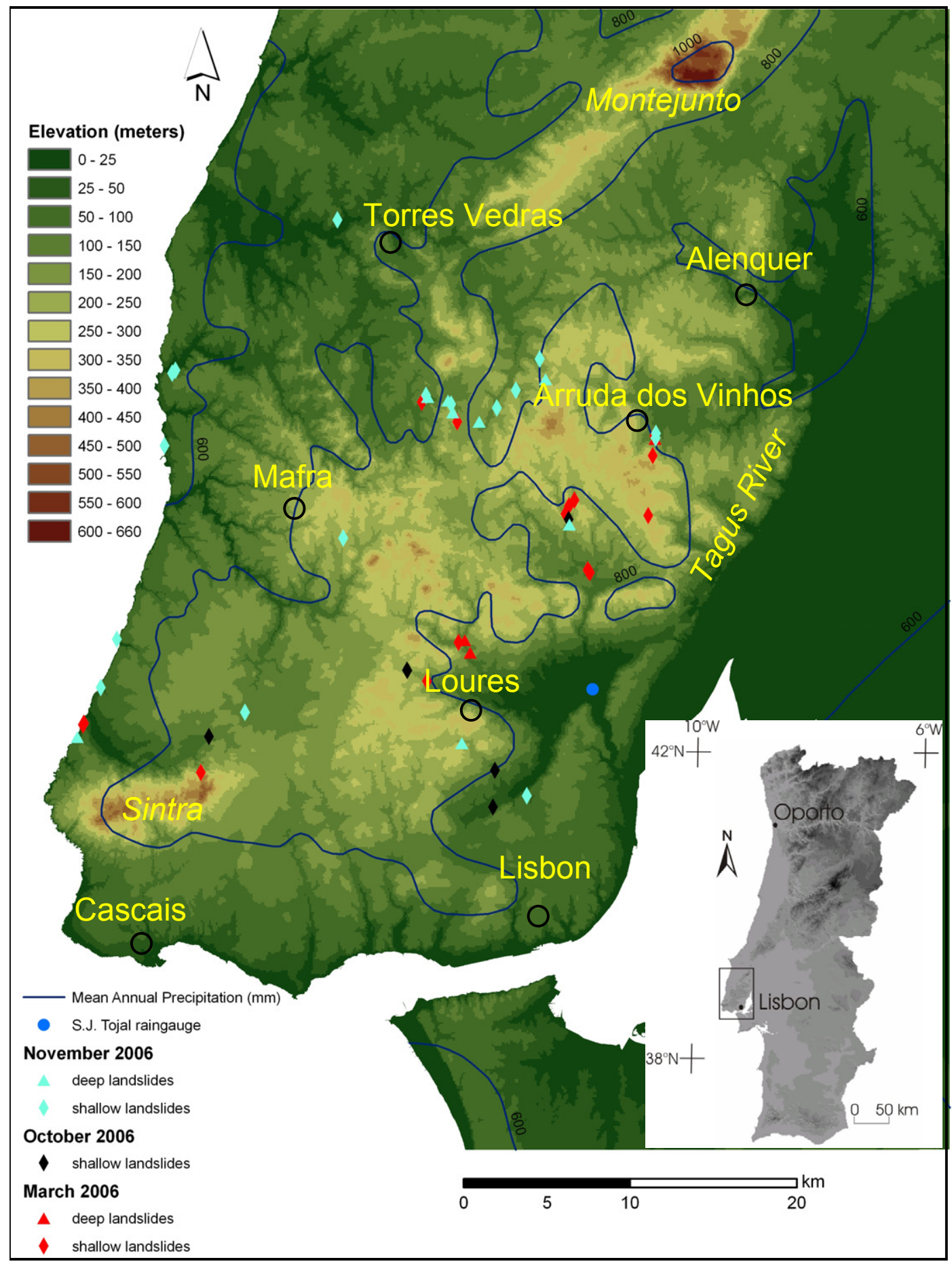

Fig. 1. Location and elevation of the study area, and distribution of landslides occurred in 2006. Mean Annual Precipitation (MAP) values for the period 1931-1960 are also represented (source: Daveau et al., 1977).

rainfall thresholds can be used to implement landslide warning systems at the local or regional level (Guzzetti et al., 2007). However, it is crucial to validate these empirical models with new rainfall and landslide events, in order to constrain the uncertainty, and to minimize the occurrence of both "false positives" (i.e. predicted landslide events that do not occur) and "false negatives" (i.e. occurred landslide events that are not predicted).

The vast majority of landslides registered in the region of Lisbon during the last 50 years were induced by rainfall; 


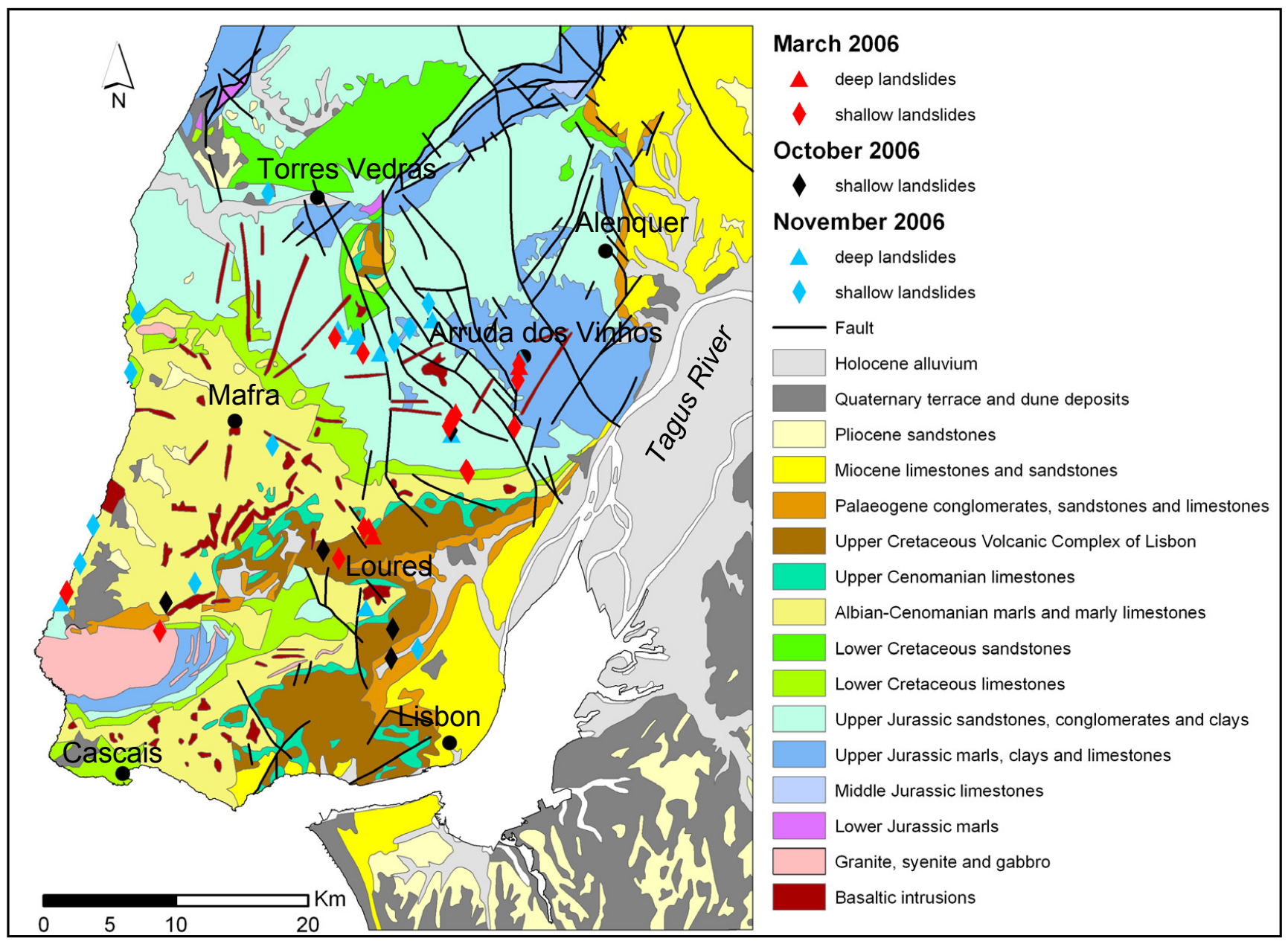

Fig. 2. Geology of the study area and distribution of landslides occurred in 2006.

therefore landslide activity has been confined to very wet periods. Previous results obtained using empirical relationships between rainfall intensity and slope instability show that critical rainfall conditions for failure are not the same for different types of landslides (Zêzere and Rodrigues, 2002; Zêzere et al., 2005; Trigo et al., 2005). A considerable fraction of these landslide events occurred immediately after intensive short bursts (1-15 days) of precipitation (e.g. November 1967 and November 1989). On the contrary, another group of landslide events took place after prolonged periods (30-90 days) of successive precipitation episodes of moderate intensity (e.g. February 1979 and January 1996). In recent years the authors have found a significant impact exerted by North Atlantic Oscillation (NAO) on the Portuguese mainland winter precipitation (Trigo et al., 2004) and over the recent landslide activity in the study area (Trigo et al., 2005; Zêzere et al., 2005). This link is related with the control that the NAO exerts, at the monthly and seasonal scales, on the storms entering from the North Atlantic Ocean and corresponding precipitation field.
In 2006, three new landslide events were registered in the Lisbon region. Therefore, the main objectives of the present study are:

1. to characterize the 2006 landslides occurred in the study area, and to discuss the rainfall regime prior to the landslide events as well as the associated atmospheric conditions that were responsible for their trigger;

2. to critically compare the new landslide events with the previously established regression models regarding rainfall intensity/duration, in order to validate critical rainfall thresholds;

3. to analyse the role played by the North Atlantic Oscillation (NAO) during those months marked by landslide activity in order to confirm the relevance of this largescale pattern of atmospheric circulation variability. 


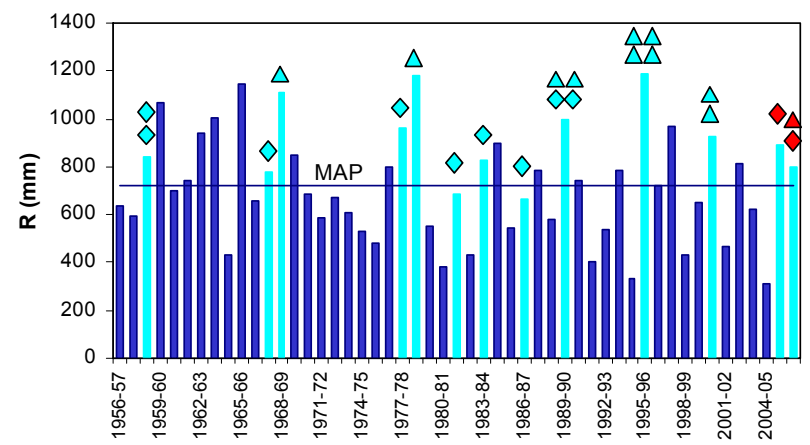

Fig. 3. Annual precipitation (climatological year) distribution at S. Julião do Tojal (reference rain-gauge) and landslide incidence from 1956/1957 to 2006/2007. MAP - Mean Annual Precipitation (723 mm). Light blue bars - years with landslide activity; Diamonds - events of shallow landslides activity; Triangles - events of deep landslides activity. Landslide events occurred in 2006 are marked in red.

\section{The study area}

The Lisbon area is part of the southern Portuguese Estremadura being limited by the Tagus River, at the East, and by the Atlantic Ocean, at the West (Fig. 1). The elevation ranges from 0 to $666 \mathrm{~m}$, and the highest area corresponds to the Montejunto Mountain that is located in the northern part of the study area. This mountain range extends from the NE to the SW over $18 \mathrm{~km}$, and corresponds to a faulted anticline affecting limestones and marls of Upper Jurassic age (Fig. 2). Another important topographic feature is the Sintra Mountain located near the Atlantic Ocean just north of Cascais (Fig. 1). This mountain extends over $10 \mathrm{~km}$ in the direction W-E, and have a maximum altitude of $528 \mathrm{~m}$. From the geological point of view, the Sintra Mountain is formed mostly by granite, syenite and gabbro (Fig. 2), corresponding to the intrusion of an igneous diapyr that occurred during the Late Cretaceous (Kulberg and Kulberg, 2000).

The Lisbon area was affected by a tectonic compressive phase during the Upper Miocene (Ribeiro et al., 1979). This tectonic phase was responsible for the creation of large ENEWSW synclines and anticlines, which affected mostly Jurassic and Cretaceous formations (Fig. 2). In the East zone of the study area, between the Montejunto Mountain and Lisbon, the differential erosion was prevalent during the Quaternary allowing the formation of a hilly landscape that does not exceed $450 \mathrm{~m}$ (Fig. 1). Such landscape includes structural landforms (e.g. cuestas) and large erosive depressions (e.g. in the area of Loures and Arruda dos Vinhos). In the western zone of the study area, a polygenic coastal plateau was constructed during the Late Pliocene and the Early Quaternary (Ferreira, 1981). This geomorphologic unit does not exceed $200 \mathrm{~m}$ (Fig. 1), and it has a gentle dip $\left(<2^{\circ}\right)$ toward the West. The fluvial erosion verified during the Quaternary promoted the degradation of the plateau, and was responsible by the creation of some steep slopes.
The climate of the Lisbon region is Mediterranean but with a significant influence of low-pressure systems originated in the Atlantic. The mean annual precipitation (MAP) ranges from $600 \mathrm{~mm}$ to $1000 \mathrm{~mm}$ (Fig. 1). At the reference rain gauge of S. Julião do Tojal (Fig. 1), the MAP is $725 \mathrm{~mm}$ (Fig. 3), and the rainfall occurs mostly from October to March (78\% of the total amount; $72 \%$ of the total rainy days). The precipitation regime is very irregular at the interannual and inter-seasonal scales, and encompasses large periods of drought, long lasting rainy periods, and very intense short rainfall episodes (Trigo et al., 2004, 2005; Zêzere et al., 2005; Paredes et al., 2006).

The Lisbon area is an important landslide-prone area in Portugal (Zêzere et al., 1999). Nineteen landslide events occurred in 11 years (Fig. 3) during the 50 year-long period that spans from 1956 to 2005 (Zêzere et al., 2005). Slope instability reported in the study area includes both shallow slope movements (e.g. shallow soil slips with slip surface depth less than $1.5 \mathrm{~m}$ and small debris flows) and more deepseated landslides (e.g. translational slides, rotational slides, complex and composite slope movements, whose slip surface depth typically ranges from 3 to $5 \mathrm{~m}$ ). Landslide activity is particularly relevant within the following lithological units (Fig. 2): (i) Upper Cretaceous Volcanic Complex of Lisbon, made up of basalts alternating with volcanic tuffs; (ii) Albian-Cenomanian marls and clays; (iii) Upper Jurassic sandstones, conglomerates and clays; and (iv) Upper Jurassic marls, clays and limestones.

\section{Landslide activity and rainfall triggering thresholds in the Lisbon region}

Previous empirical relationships between rainfall and landslide activity established for the study area have been based on the computation of cumulative absolute antecedent rainfall for $1,2,3,4,5,10,15,30,40,60,75$, and 90 consecutive days. The return period of the obtained rainfall amountduration combinations were assessed by applying the Gumbel distribution (Gumbel, 1958), and the critical combination responsible for each landslide event has been assumed as the rainfall pair (quantity-duration) with the highest return period (Trigo et al., 2005; Zêzere et al., 2005). Although this assumption has not a physical basis, it provides the best discrimination between rainfall periods characterised by landslide activity and rainfall periods not related with slope instability (Zêzere et al., 2005). The study of rainfall conditions responsible for the trigger of past landslide events in the study area also includes the reconstruction of calibrated antecedent rainfall $(C A R)$ for 3, 10, 15 and 30 days, by applying the algorithm initially introduced by Crozier (1986):

$C A R x=K P 1+K^{2} P 2+\ldots K^{n} P n$

where $C A R x$ is the calibrated antecedent rainfall for day $\mathrm{x}$; $P 1$ is the daily rainfall observed for the day before day $\mathrm{x} ; P n$ 
is the daily rainfall registered for the $\mathrm{n}$-th day before day $\mathrm{x}$; and $K$ (assumed to be 0.9) is the empirical parameter that accounts for the decrease of the impact of a particular rainy event in time due to drainage processes.

Following the approach used by the authors, daily precipitation data for the reference rain gauge of S. Julião do Tojal (Fig. 1) was used to derive a general trend relating rainfall amount and the rainfall critical duration for 19 landslide events registered between 1956 and 2005 (Trigo et al., 2005). The regression line is given by the equation $C r=7.4 D+107\left(R^{2}=0.94\right)$ where $C r$ is the cumulative rainfall in $\mathrm{mm}$, and $D$ is the duration in days. Additionally, the combination of the rainfall intensity and the critical rainfall duration produced a regression curve following the equation $R i=84.3 D^{-0.57}\left(R^{2}=0.88\right)$, where $R i$ is the rainfall intensity in $\mathrm{mm} /$ day and $D$ is the duration of rainfall in days (Zêzere et al., 2005).

The comparison between the total area affected by shallow and deep slope movements within each landslide event was the criterion used to distinguish between shallow and deep landslide events. Deep (shallow) landslide events are characterised by more than $50 \%$ of landslide area associated to slip surfaces depth $>1.5 \mathrm{~m}$ (depth $<1.5 \mathrm{~m}$ ). The distinction between landslide events concerning the number of days relevant to the antecedent rainfall was confirmed by combining the daily rainfall and the $C A R$. The best results obtained for shallow landslide events were attained with the combination between the daily rainfall and the 5 days $C A R$ through the exponential rule $D r=167.28 e^{-0.0355 C A R}$, where $D r$ is the daily rainfall. On the other hand, deep landslide events are better discriminated by a combined threshold of daily rainfall $=16 \mathrm{~mm}$ and 30 days $C A R=85 \mathrm{~mm}$ (Zêzere et al., 2005). The different time span is consistent with the distinct hydrological triggering conditions related to different types of landslides. Intense rainfall is responsible by the rapid growth of pore water pressure and by the loss of the apparent cohesion of thin soils, resulting in failure within the soil material or at the contact with the underlying impermeable bedrock (Gostelow, 1991; Iverson, 2000). Long duration, but less intense, rainfall periods allow the steady rise of the groundwater table and the occurrence of deep failures by the reduction of shear strength of affected materials (Van Asch et al., 1999; Iverson, 2000).

\section{Rainfall-triggered landslide events in the Lisbon re- gion over 2006}

In 2006, three new rainfall-triggered landslide events occurred in the Lisbon region, namely on the 20 March, the 25-27 October, and the 28 November. During these three events we have identified and characterised about 51 individual landslide occurrences (Fig. 1). Table 1 summarizes the rainfall amount - duration combinations observed at S. Julião do Tojal and the corresponding return period for the three landslide events, that were obtained applying the same rationale used in previous work developed for the study area (Trigo et al., 2005; Zêzere et al., 2005).

\subsection{The 20 March 2006 event}

The beginning of the climatological year of 2005-2006 was dry (9 September, $9 \mathrm{~mm}$ ), but the precipitation registered in October $(121 \mathrm{~mm})$ and November $(156 \mathrm{~mm})$ was above the monthly average (32 $\mathrm{mm}$ and $43 \mathrm{~mm}$, respectively). Rainfall decreases in December 2005 and January $2006(62 \mathrm{~mm}$ and $68 \mathrm{~mm}$, respectively; $45.5 \mathrm{~mm}$ and $32 \mathrm{~mm}$ below monthly averages). February was slightly wet $(103 \mathrm{~mm}, 12 \mathrm{~mm}$ above monthly average), and March registered $267 \mathrm{~mm}$. The last feature is the absolute maximum for this month in a 50years period, and surpasses 3.9 times the monthly average (69 mm).

Figure 4a illustrates the evolution of antecedent rainfall for different durations ( 1 to 60 days) at S. Julião do Tojal from September 2005 to April 2006. According to the above mentioned criteria used to define the critical rainfall combination (amount/duration), the landslide event occurred on 20 March was related with an intense rainfall concentrated in just 4 days (Table 2). The total rainfall for this period was $155.8 \mathrm{~mm}$ (i.e. more than twice the March average), and the corresponding rainfall intensity was $39 \mathrm{~mm} /$ day (Table 2). The return period obtained for this rainfall episode was 12.9 years. Figure5a shows the distribution of the 4-days cumulative rainfall for the 20 March 2006, that was obtained after interpolating the rainfall data available for twenty rain gauges located in the study area. The landslides concentrate in areas where the 4-days cumulative rainfall was above $50 \mathrm{~mm}$, and the maximum intensity of the rainfall episode was constrained in the area of S. Julião do Tojal and Loures.

The atmospheric conditions responsible for this landslide event were dominated by the influence of a cut-off low system. A cut-off low (COL) corresponds to a closed low in the upper troposphere that has become completely detached (cut off) from the basic westerly current usually being advected equatorward of the mid-latitude westerlies (Nieto et al., 2005). These systems are slow moving and often stay over the same region for several days, therefore capable of considerably affecting the weather conditions felt at the surface (Gimeno et al., 2007). Using National Centers for Environmental Prediction/National Center for Atmospheric Research (NCEP/NCAR) reanalysis-2 data (obtained in the NOAA Operational Model Archive Distribution System NOMADS - website), different features of this COL are represented in Fig. 6, illustrating some relevant factors that explain the occurrence of persistent and abundant rainfall over the Portuguese area. Taking into account the position of the surface low centre (a weak low, with central minimum pressure slightly below $996 \mathrm{hPa}$, Fig. 6a) it is possible to recognize the presence of a south-westerly flow at the lower levels. During the four days of this event the COL system moved 
Table 1. Cumulative rainfall from 1 to 90 days and corresponding return periods for landslide events in the Lisbon region over 2006. Rainfall data from S. Julião do Tojal; R - Rainfall (mm); R.P. - Return Period (years). Critical rainfall amount-duration is marked in bold.

\begin{tabular}{lcccccccccccccc}
\hline $\begin{array}{l}\text { Landslide } \\
\text { events }\end{array}$ & Date & & $\begin{array}{c}1 \\
\text { day }\end{array}$ & $\begin{array}{c}2 \\
\text { days }\end{array}$ & $\begin{array}{c}3 \\
\text { days }\end{array}$ & $\begin{array}{c}4 \\
\text { days }\end{array}$ & $\begin{array}{c}5 \\
\text { days }\end{array}$ & $\begin{array}{c}10 \\
\text { days }\end{array}$ & $\begin{array}{c}15 \\
\text { days }\end{array}$ & $\begin{array}{c}30 \\
\text { days }\end{array}$ & $\begin{array}{c}40 \\
\text { days }\end{array}$ & $\begin{array}{c}60 \\
\text { days }\end{array}$ & $\begin{array}{c}75 \\
\text { days }\end{array}$ & $\begin{array}{c}90 \\
\text { days }\end{array}$ \\
\hline 2006-A & $20-03-06$ & R (mm) & 42.1 & 63.0 & 100.4 & $\mathbf{1 5 5 . 8}$ & 155.8 & 156.1 & 157.4 & 298.6 & 299.5 & 358.3 & 386.8 & 418.9 \\
& & R.P. (y) & 1.6 & 1.8 & 3.6 & $\mathbf{1 2 . 9}$ & 8.1 & 3 & 2 & 4 & 2.7 & 2.6 & 2.4 & 2.3 \\
\hline \multirow{2}{*}{$2006-B$} & $27-10-06$ & R (mm) & 26.0 & 34.2 & 103.5 & 104.7 & 149.9 & $\mathbf{2 1 8 . 5}$ & 234.2 & 241.3 & 276.0 & 277.8 & 284.0 & 284.1 \\
& & R.P. (y) & 1.2 & 1.1 & 3.9 & 2.8 & 6.9 & $\mathbf{1 0 . 1}$ & 5.7 & 2.3 & 2.2 & 1.6 & 1.5 & 1.3 \\
\hline \multirow{2}{*}{$2006-$ C } & $28-11-06$ & R (mm) & 36.5 & 42.9 & 44.7 & 80.6 & 116.7 & 121.2 & 172.0 & 229.0 & $\mathbf{4 2 7 . 1}$ & 470.1 & 505.5 & 506.9 \\
& & R.P. (y) & 1.4 & 1.2 & 1.1 & 1.6 & 2.9 & 1.7 & 2.4 & 2.1 & $\mathbf{8 . 2}$ & 5.7 & 5.1 & 3.8 \\
\hline
\end{tabular}
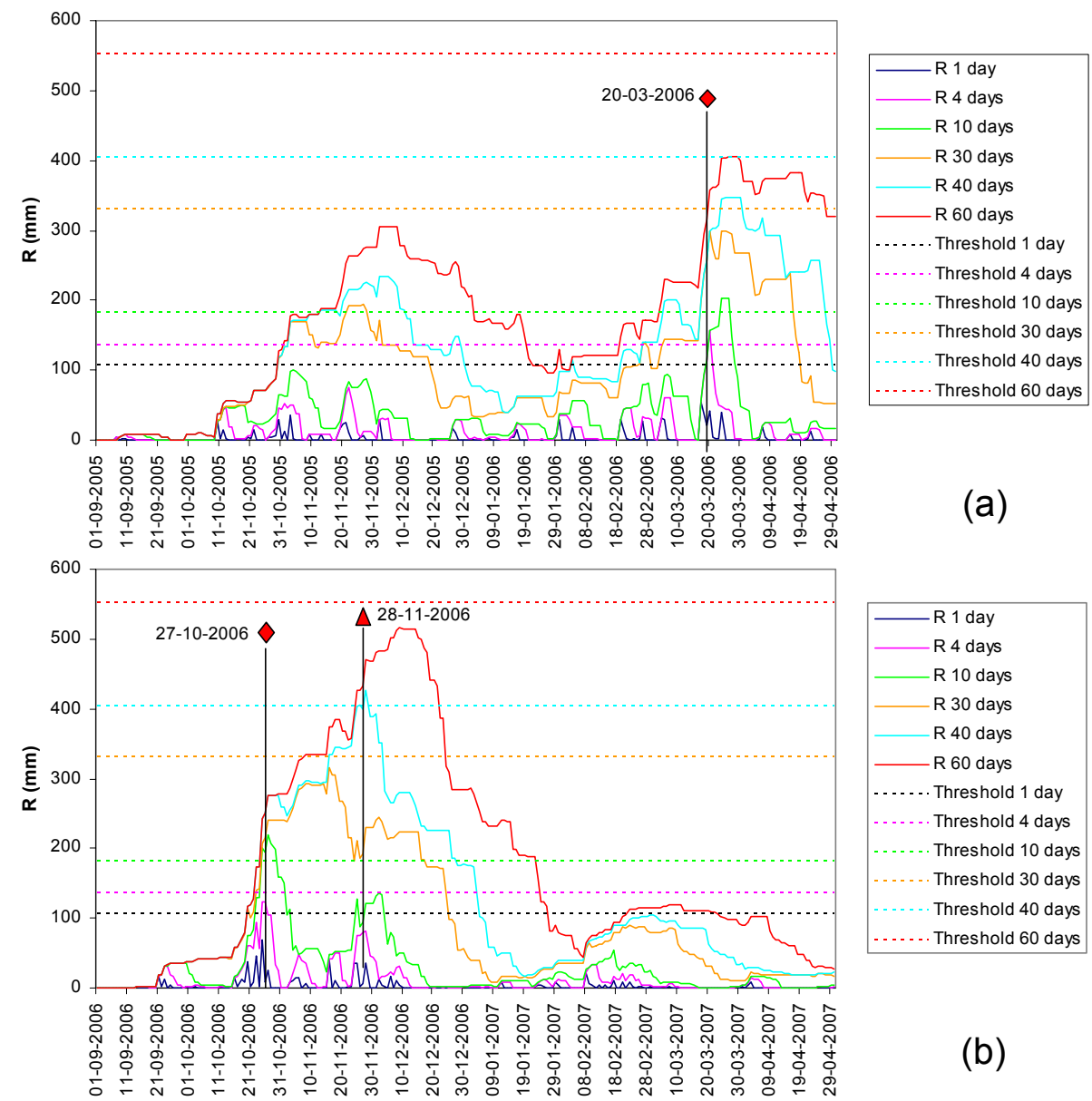

(a)

Fig. 4. Cumulative rainfall for different rainfall durations and corresponding rainfall thresholds in S. Julião do Tojal. (a) from September 2005 to April 2006; (b) from September 2006 to April 2007.

slowly from SW to NE where it reached its final stage on the 20 March, when the COL's centre stationed over the Spanish north-western province of Galicia. The cloudiness associated with the activity of this COL was predominantly of the convective type and its development occurred mainly at the advancing edge of the system, causing abundant rainfall over
Southern Portugal. On the 17 March the western sector of the Portuguese territory was particularly affected by intense rainfall ( $55.4 \mathrm{~mm}$ at $\mathrm{S}$. Julião do Tojal), as suggested by the convective precipitation rate field represented in Fig. 6c.

The 20 March event triggered 21 individual landslides (Fig. 1) that were mostly shallow slope movements (18 out of 
Table 2. Landslide incidence and critical rainfall conditions for landslide events in the Lisbon region over 2006 (Rainfall data from S. Julião do Tojal).

\begin{tabular}{llllll}
\hline $\begin{array}{l}\text { Landslide } \\
\text { event }\end{array}$ & Date & $\begin{array}{l}\text { Critical rainfall amount/ } \\
\text { duration (mm; days) }\end{array}$ & $\begin{array}{l}\text { Rainfall intensity/du- } \\
\text { ration (mm/day; days) }\end{array}$ & $\begin{array}{l}\text { Return Period } \\
\text { (years) }\end{array}$ & Landslide occurrence \\
\hline 2006-A & $20-03-06$ & $155.8 ; 4$ & $39.0 ; 4$ & 12.9 & $\begin{array}{l}18 \text { shallow slides } \\
3 \text { deep slides }\end{array}$ \\
\hline 2006-B & $27-10-06$ & $218.5 ; 10$ & $21.9 ; 10$ & 10.1 & 6 shallow slides \\
\hline 2006-C & $28-11-06$ & $470.1 ; 40$ & $10.7 ; 40$ & 8.2 & $\begin{array}{l}16 \text { shallow slides } \\
8 \text { deep slides }\end{array}$ \\
\hline
\end{tabular}

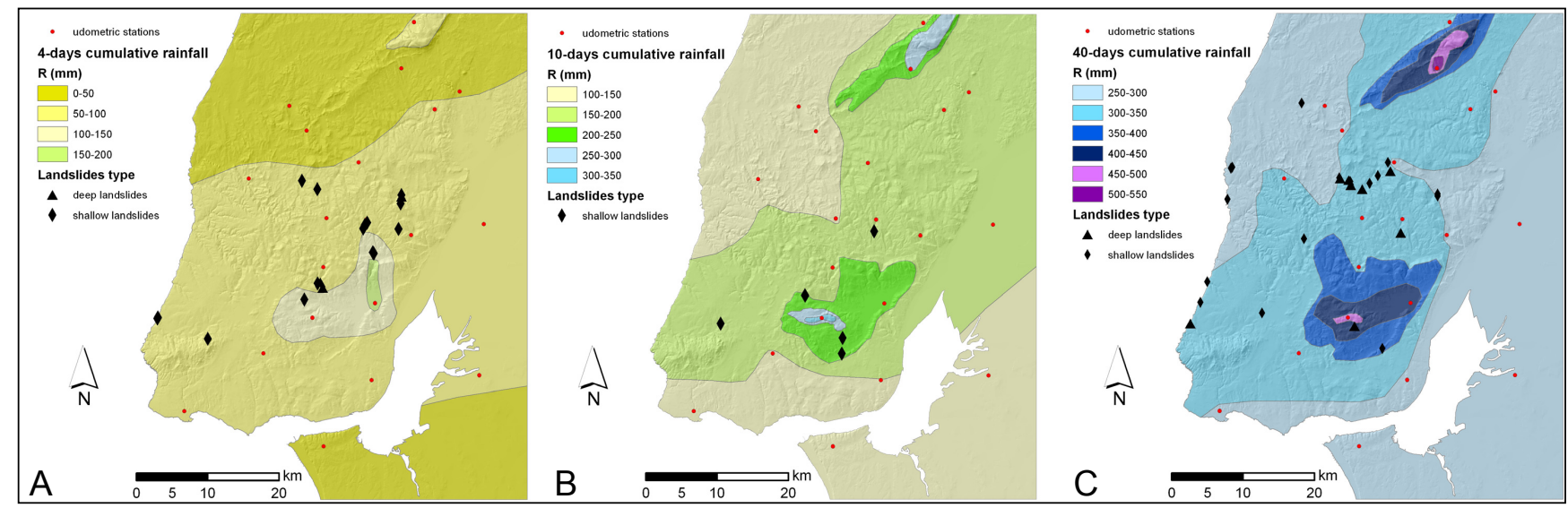

Fig. 5. Critical cumulative rainfall distribution and landslide incidence in the Lisbon area for the 2006 landslide events. (A) 4-days cumulative rainfall registered in 20 March 2006; (B) 10-days cumulative rainfall registered in 27 October 2006; (C) 40-days cumulative rainfall registered in 28 November 2006.

21 ), with failure depth lower than $1.5 \mathrm{~m}$, including 13 shallow translational slides, 2 shallow rotational slides, and 3 debris flows shifted from shallow landslides (Table 2). Individual examples of these shallow landslides can be appreciated in Fig. 7. Additionally, there were also 3 rotational slides with slip surface deeper than $1.5 \mathrm{~m}$. Landslides distribute mostly on the sedimentary formations of Upper Jurassic age (Table 3, Fig. 2): 12 cases, 57\% of total registered landslides.

\subsection{The 25-27 October 2006 event}

Rainfall occurrence was observed to be close to average during the first month of the 2006-2007 climatological year ( $38 \mathrm{~mm}$ in September, $8 \mathrm{~mm}$ above the monthly average). However, October registered $240 \mathrm{~mm}$, i.e. 2.7 times the corresponding monthly average. Figure $4 \mathrm{~b}$ illustrates the evolution of antecedent rainfall for different durations (1 to 60 days) at S. Julião do Tojal from September 2006 to April 2007. The precipitation was very intense during the second half of October; in this period, daily rainfall surpassed $25 \mathrm{~mm}$ in four distinct occasions, and the yearly maximum was observed on the 25 October $(69.3 \mathrm{~mm})$. The critical rainfall conditions for the landslide event were found to be $218.5 \mathrm{~mm}$ in 10 consecutive days (Table 2). The corresponding rainfall intensity was $22 \mathrm{~mm} / \mathrm{day}$, and the return period of the precipitation event is 10.1 years. The maximum cumulative rainfall was observed in the Montejunto Mountain and in the Loures area (Fig. 5b), and most landslides distribute in areas where the 10-days cumulative rainfall was above $200 \mathrm{~mm}$.

This event includes two distinct periods, a short and moderate rainy burst, followed by a torrential rainfall episode in the Lisbon area. This later torrential episode began at noon on the 24 October and finished in the early morning of the following day, corresponding to a total duration of just $18 \mathrm{~h}$. The total rainfall registered for this episode exceeded $69 \mathrm{~mm}$ in S. Julião do Tojal, and $88 \mathrm{~mm}$ in Penedos de Alenquer, located in the south flank of the Montejunto Mountain (164 m a.s.l).

The synoptic scale atmospheric circulation over the Iberian Peninsula during this two days period was controlled by an extratropical cyclone located NW of Portugal as shown at $0: 00 \mathrm{~h}$ on the 25 October (Fig. 8a). Figure 8a also shows a deep upper level trough (at the $500 \mathrm{hPa}$ geopotential height surface) located west of Portugal. At the surface and lower levels, the cyclonic circulation prompted the advection of 


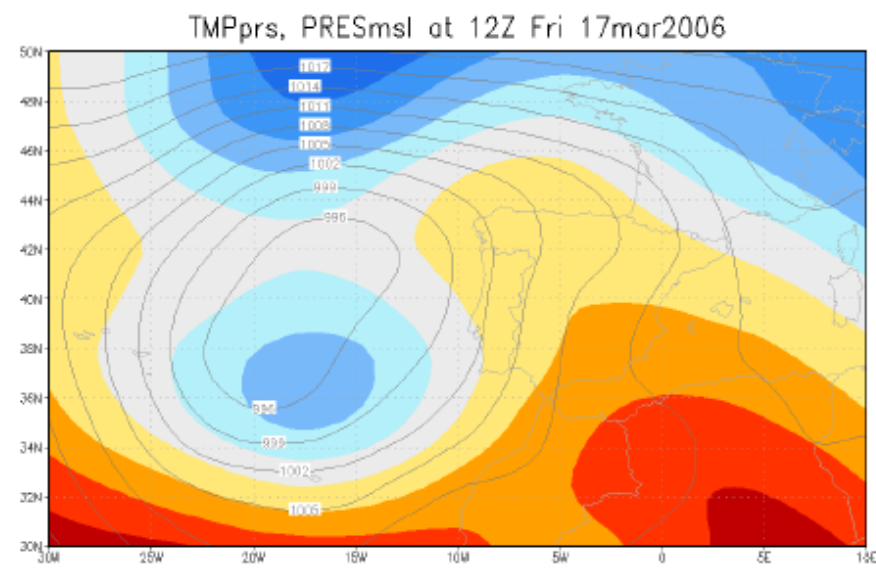

A

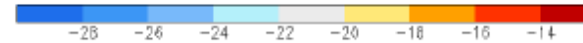

CPRATsfC 12Z17MAR2006
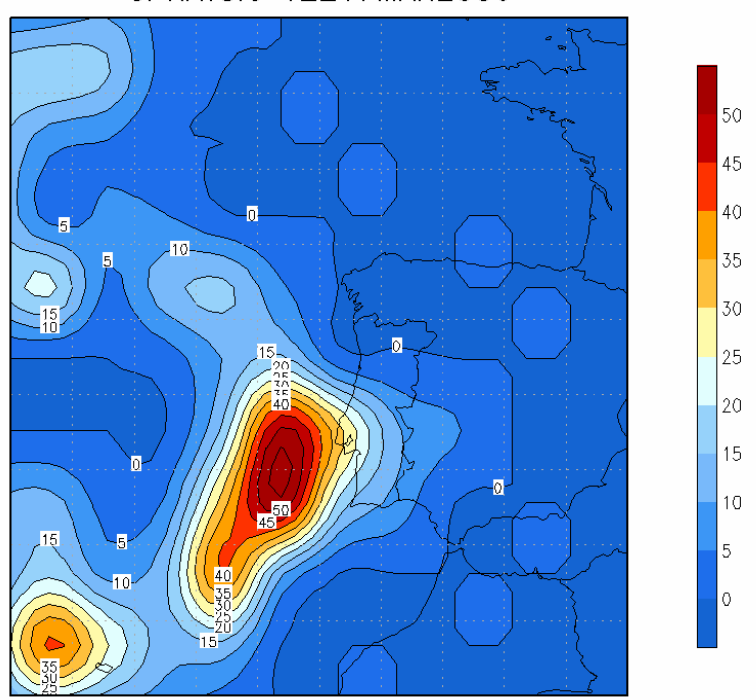

HGTprs, PRESmsl at $12 Z$ Sat 18 mor2006
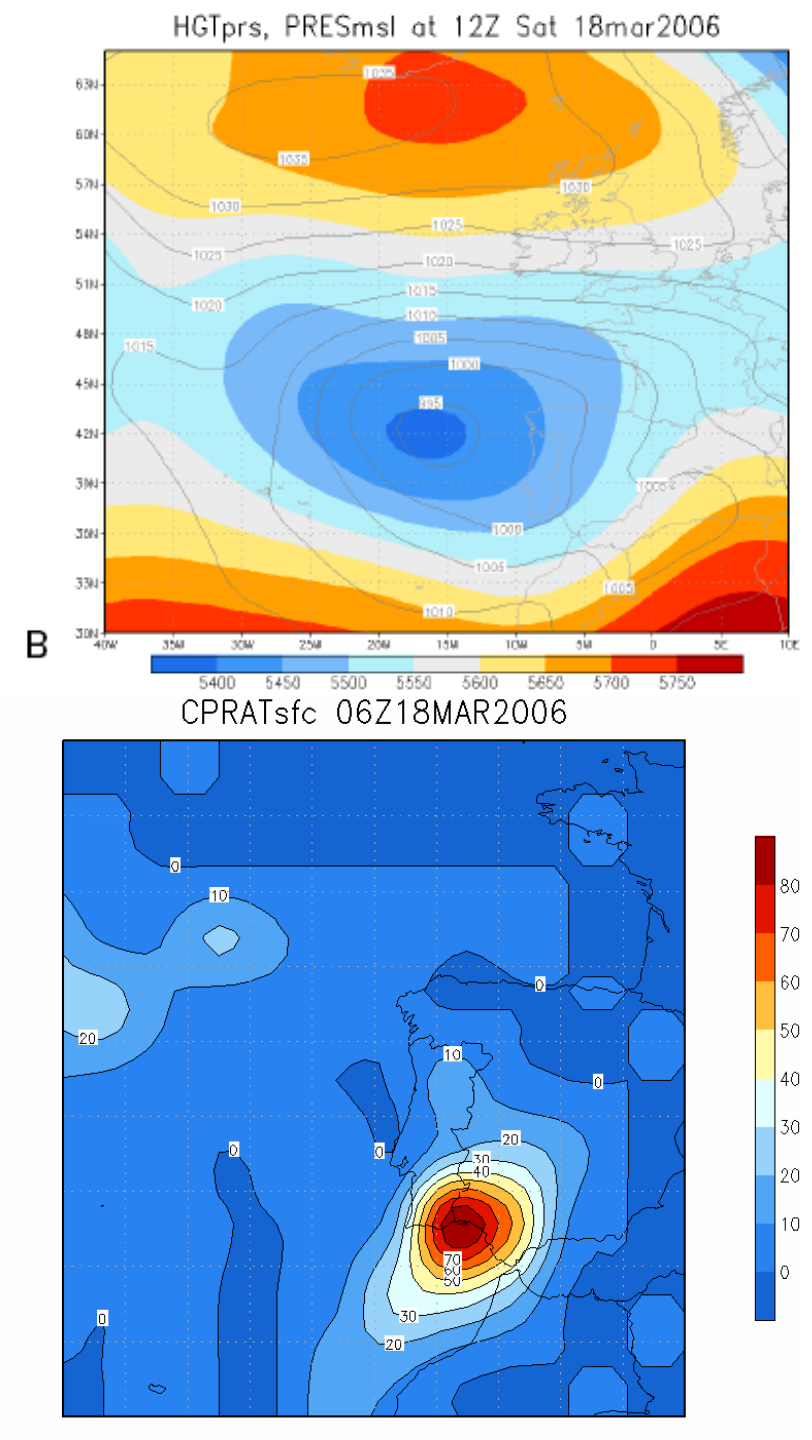

C

D

Fig. 6. The Cut-off low (COL) system affecting the Portuguese area, 17-18 March 2006. (A) sea level pressure (hPa, lines) and air temperature at $500 \mathrm{hPa}$ (in ${ }^{\circ} \mathrm{C}$, colours), 17 March, 00:00 p.m.; (B) sea level pressure (hPa, lines) and 500 hPa geopotential heights (metres, colours), 18 March, 00:00 p.m.; (C) and (D) convective precipitation rate (mm/day) on 17 March (00:00 p.m.) and 18 March (06:00 a.m.), respectively. Source: Reanalysis-2 data.

warm and moist air from the SW, contributing to the establishment of an instability band. Several convective cloud systems embedded in this band have caused thunderstorms producing intense rainfall over small areas. Figure 8 (b, c and d) illustrates the sequence of convective precipitation rate obtained for three moments separated by $6 \mathrm{~h}$. This sequence clearly shows that the region just north of Lisbon was particularly affected by the precipitation associated with these convective cells.

Six shallow soil slips were triggered during the 25-27 October event (Table 3, Fig. 2). Three slope movements affected basalts and volcanic tuffs belonging to the Upper Cre- taceous Volcanic Complex of Lisbon (Fig. 7) and the remaining distribute on Palaeogene, Albian-Cenomanian, and Upper Jurassic sedimentary formations.

\subsection{The 28 November 2006 event}

In November, $229 \mathrm{~mm}$ were registered at S. Julião do Tojal, i.e. more than double the monthly average. Some intense showers occurred throughout the second half of this month (Fig. 4b), namely on the $24-25(72 \mathrm{~mm})$ and the 28 $(36.5 \mathrm{~mm})$. The landslide event was related with an accumulated rainfall value of $470 \mathrm{~mm}$ registered for the prolonged 40-days period (Table 2). The cumulative precipitation for 
Table 3. Landslide incidence on lithological units (number of slope movements) for landslide events in the Lisbon region during 2006 (SL shallow landslides; DL - deep landslides).

\begin{tabular}{|c|c|c|c|c|c|c|c|c|}
\hline \multirow{3}{*}{ Lithological Unit } & \multicolumn{8}{|c|}{2006 landslide events } \\
\hline & \multicolumn{2}{|c|}{20 Mar 2006} & \multicolumn{2}{|c|}{$25 / 27$ Oct 2006} & \multicolumn{2}{|c|}{28 Nov 2006} & \multirow[b]{2}{*}{ Total } & \multirow[b]{2}{*}{$(\%)$} \\
\hline & SL & DL & SL & DL & SL & $\mathrm{DL}$ & & \\
\hline \multicolumn{9}{|l|}{ Holocene alluvium } \\
\hline \multicolumn{9}{|l|}{ Quaternary terrace and dune deposits } \\
\hline \multicolumn{9}{|l|}{ Pliocene sandstones } \\
\hline \multicolumn{9}{|l|}{ Miocene limestones and sandstones } \\
\hline Palaeogene conglomerates, sandstones and limestones & 4 & & 1 & & 1 & 1 & 7 & 13.7 \\
\hline Upper Cretaceous volcanic complex of Lisbon & 1 & 1 & 3 & & & & 5 & 9.8 \\
\hline \multicolumn{9}{|l|}{ Upper Cenomanian limestones } \\
\hline Albian-Cenomanian marls and marly limestones & 1 & 1 & 1 & & 4 & 1 & 8 & 15.7 \\
\hline Lower Cretaceous sandstones & & & & & 3 & & 3 & 5.9 \\
\hline \multicolumn{9}{|l|}{ Lower Cretaceous limestones } \\
\hline Upper Jurassic sandstones, conglomerates and clays & 8 & & 1 & & 6 & 6 & 21 & 41.2 \\
\hline Upper Jurassic marls, clays and limestones & 3 & 1 & & & 2 & & 6 & 11.8 \\
\hline \multicolumn{9}{|l|}{ Middle Jurassic limestones } \\
\hline \multicolumn{9}{|l|}{ Lower Jurassic marls } \\
\hline Granite, syenite and gabbro & 1 & & & & & & 1 & 2.0 \\
\hline \multicolumn{9}{|l|}{ Basaltic intrusions } \\
\hline Total & 18 & 3 & 6 & & 16 & 8 & 51 & 100.0 \\
\hline
\end{tabular}

the selected period was higher than the winter average, corresponding to roughly two-thirds of the MAP. The corresponding rainfall intensity was $11 \mathrm{~mm} /$ day, and the return period of the precipitation event is 8.2 years. The 40-days cumulative rainfall was abundant along a SW-NE direction zone where most landslides were observed (Fig. 5c). Like for the October episode, the maximum rainfall was verified in two spots within that zone: the Montejunto Mountain and the Loures area (Fig. 5c).

In addition to the antecedent rainfall conditions, this landslide event is associated with a wet spell occurred between the 23 and 28 November. In this period the mid and upperlevel circulation was dominated by intense westerlies over the Eastern Atlantic, conditioning the activity of frontal lows moving into the European shores. Two major rainstorms were caused by similar synoptic circulation conditions, and, for both rainy episodes, the origin of rainfall was closely linked with the activity of cold fronts. Here we have concentrated our analysis on the second rainstorm (27-28 November), because this episode contributed more decisively to trigger the landslide event. The most relevant features of the atmospheric circulation for the low and mid tropospheric levels are shown in Fig. 9a. We present also the corresponding infra-red meteosat image (MSG-IR), illustrating the presence of the cold front cloud system on the 27 November (at 06:00 h), precisely before reaching the Lisbon region (Fig. 9c). The active cold front system crossed the Portuguese territory from the SW to the NE during the late afternoon and the night of the 27 and at the daybreak of the 28
November. On the 27 November (18:00 h), the high moisture content of the air mass moving into Portugal is confirmed by the peak values of precipitable water (above $30 \mathrm{~mm}$ ) oriented with a SW-NE axis (Fig. 9b). Consequently several convective cloud systems were formed near western Iberia (Fig. 9c), producing abundant rainfall over large areas of Portugal (Fig. 9d). The Lisbon area was affected by intense showers, with immediate consequences for landslide activity, taking into account the antecedent precipitation observed in the previous weeks.

The 28 November event triggered 24 individual landslides (Figs. 1 and 6), including 7 rotational and 1 translational slides with deep slip surfaces. Thus this event produced, on average, deeper landslides than the corresponding slope movements described previously for late October. The remaining 16 landslides are soil slips (shallow translational slides, 13 cases; shallow rotational slides, 3 cases). The majority of landslides registered in November 2006, including 6 deep slope movements, distribute on sedimentary formations of Upper Jurassic age (Table 3, Fig. 2). Other lithological units affected by slope instability during this event are the Palaeogene, Albian-Cenomanian and Lower Cretaceous sedimentary formations.

\section{Validation of rainfall thresholds}

It is of paramount importance to contextualize the new landslide events that have occurred in 2006, namely by a critical comparison of these events with the regression 

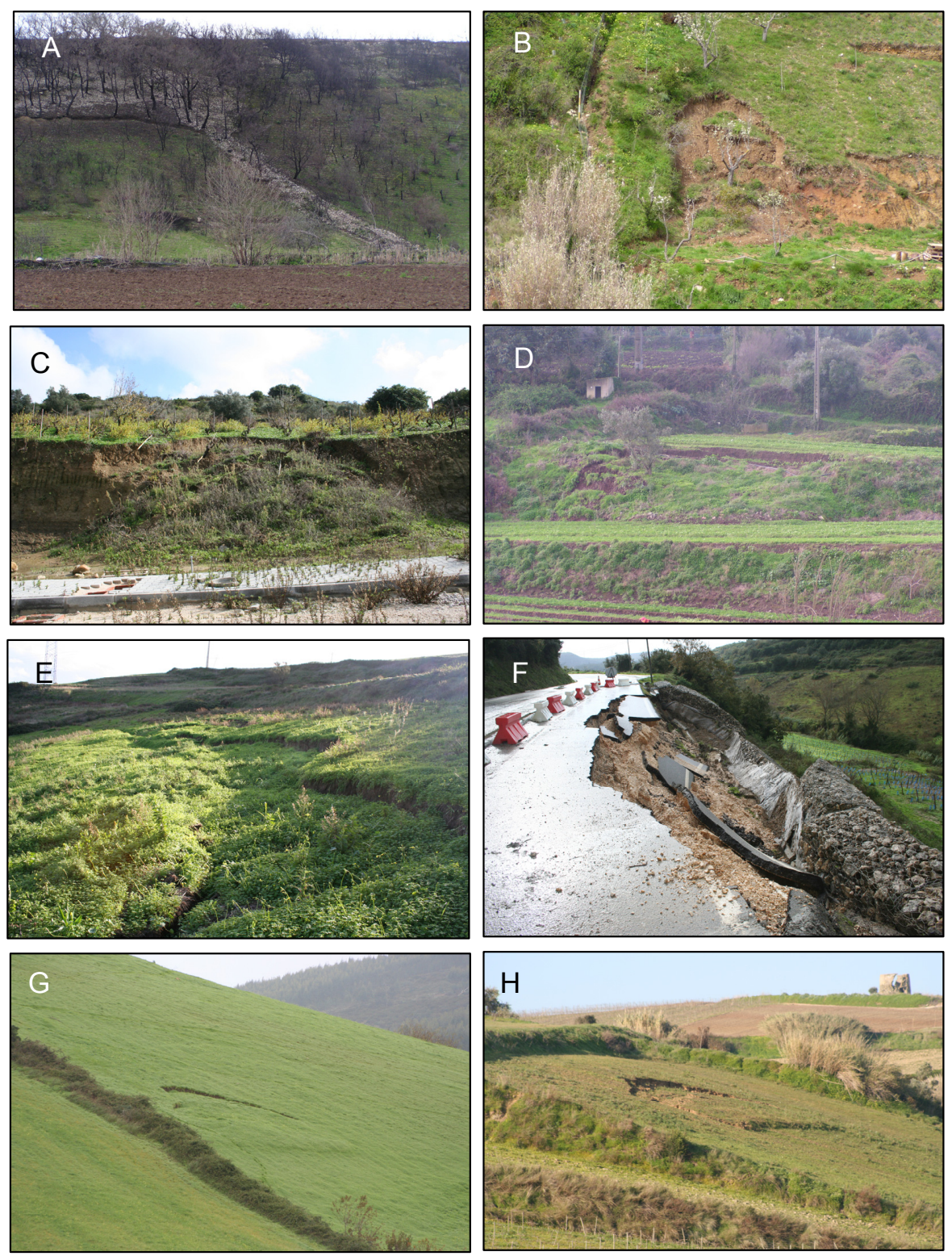

Fig. 7. Landslides triggered by rainfall in 2006 in the Lisbon Region. (A) debris flow occurred in Bucelas (20 March 2006); (B) and (C) shallow soil slips occurred near Arruda dos Vinhos (20 March 2006); (D) shallow rotational slide occurred near Loures (27 October 2006); (E) translational slide occurred in Enxara (28 November 2006); (F) rotational slide occurred in Alrota (28 November 2006); (G) and (H) shallow soil slips occurred near Torres Vedras (28 November 2006).

models regarding rainfall amount/duration previously fit for the study area (Sect. 3). Only this type of application to independent data (i.e. not used in any way during the calibration process) will allow us to validate regional rainfall thresholds for landslide activity. Figure 10 shows the regression line between the critical cumulative rainfall amount and the corresponding rainfall event duration for 19 landslide events occurred between 1956 and 2005. We plot on this figure the three landslide events observed in 2006, and all of them fall above the threshold defined by the regression model $(C r=7.4 D+107$, deduced previously in Trigo et al., 2005).
The above mentioned regression model was used to automatically derive the minimum daily rainfall needed to reach the precipitation triggering threshold at S. Julião do Tojal, for any of the following consecutive days: 1, 2, 3, 4, 5, 10, $15,30,40,60,75$ and 90 . This calculation accounts for the continuous cumulative absolute antecedent rainfall, and it is shown in Fig. 11a for the period that spans between 2000 and 2007. The landslide events occurred in March, October and November 2006 are marked in Fig. 11b and $\mathrm{c}$, and evidence a remarkable temporal constraint that confirms the ability of our model to predict such landslide events. 

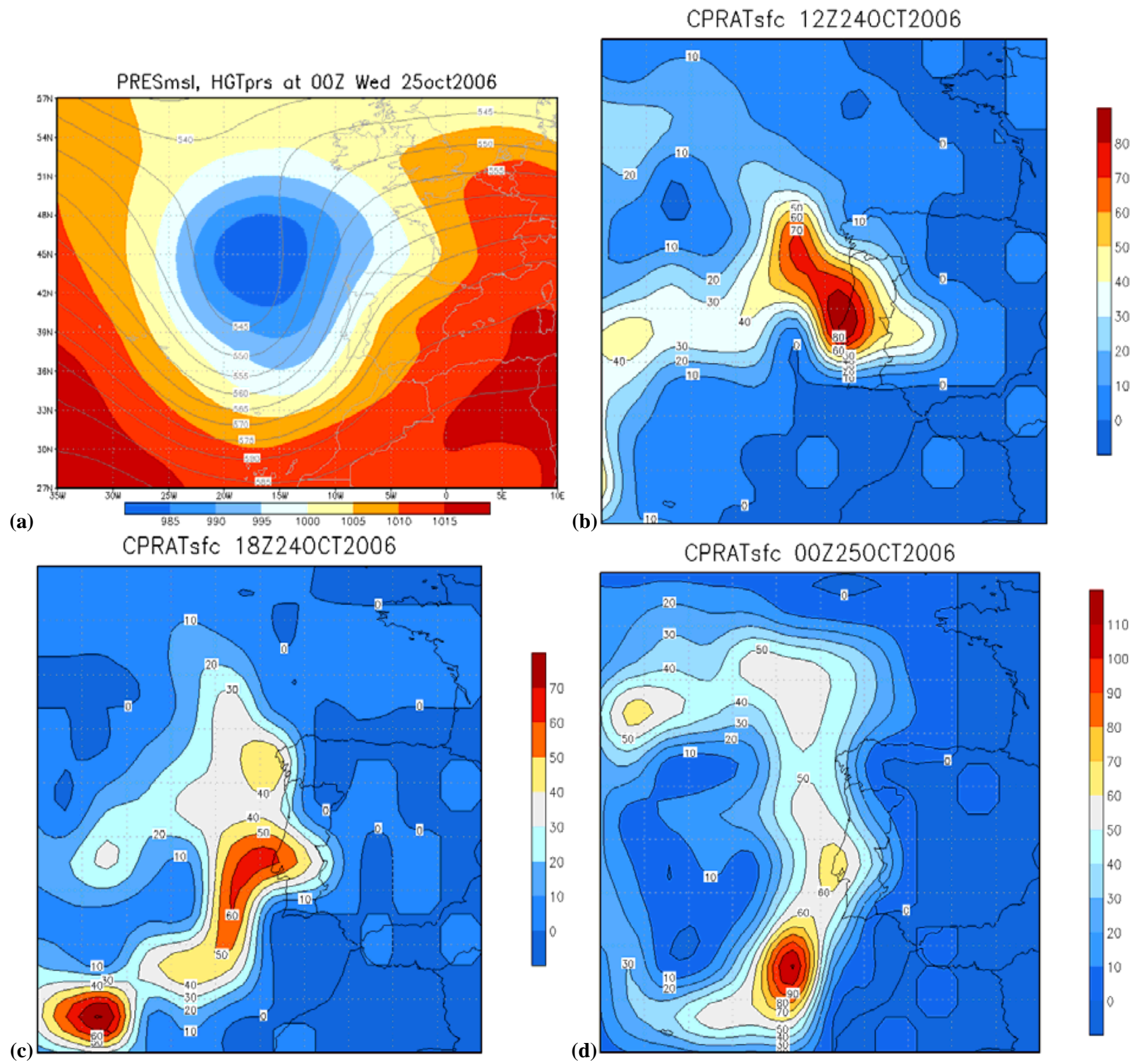

Fig. 8. The frontal cyclone affecting the Portuguese area, 25 October 2006. (a) Sea level pressure (hPa, colours) and $500 \mathrm{hPa}$ geopotential heights (decametres, lines); (b, c and d) convective precipitation rate ( $\mathrm{mm} /$ day) over the Portuguese area on the 24 October, 12:00, 18:00, and the 25 October, 00:00. Source: Reanalysis-2 data.

Figure 11a also shows a landslide event occurred in January 2001 that was described in previous works (Zêzere and Rodrigues, 2002; Trigo et al., 2005; Zêzere et al., 2005). From January 2001 to March 2006 the regional rainfall threshold was never reached, and simultaneously, no landslide activity was reported for the Lisbon region during this period. Therefore, from 2001 to 2007, our model did not predict landslide events that did not occur (i.e. "false positives"), and there is no evidence of unpredicted landslide events (i.e. "false negatives").
As it was previously referred, the pre-existing regional rainfall thresholds for landsliding also account the $C A R$ (Zêzere et al., 2005). Figure 12 shows the combination of the daily rainfall with the corresponding $C A R$ for 5 (a), 10 (b), 15 (c) and 30 (d) days. The empirical drawn rules were defined taking into account data relative to the 19 reported landslides events for the period 1956-2005 (adapted from Zêzere et al., 2005). Table 4 summarizes results of calibrated antecedent rainfall for the three landslide events verified in the Lisbon region during 2006. When we plot these data on 


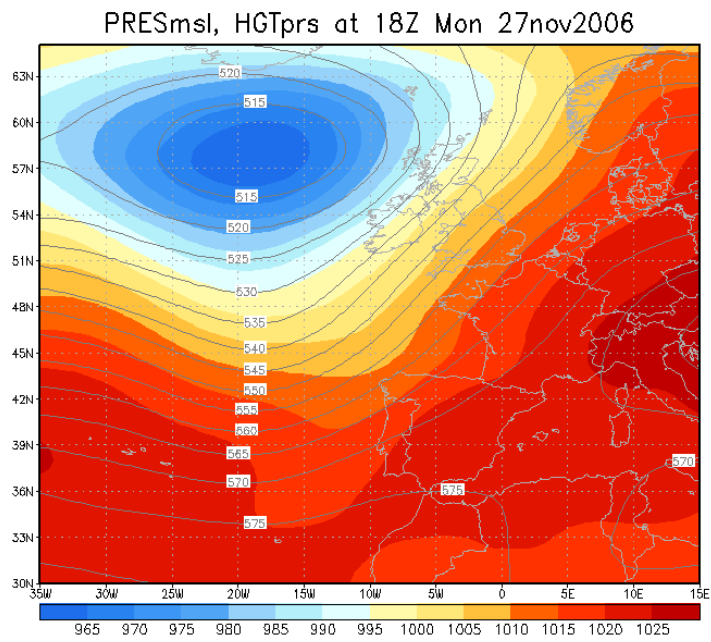

A

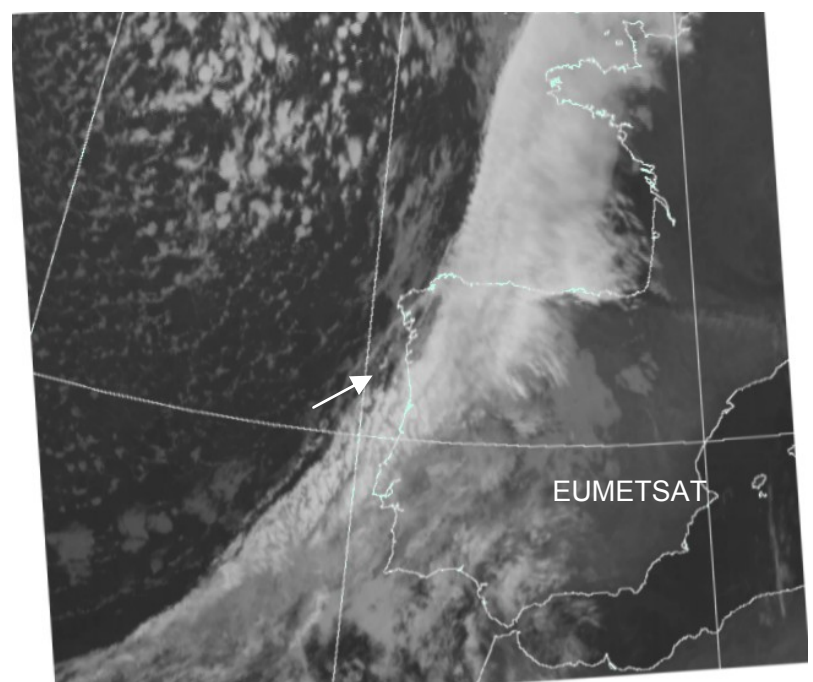

C

Fig. 9. The frontal cyclone affecting the Portuguese area, 27 November 2006 (18:00 h). (A) sea level pressure (hPa, colours) and 500 hPa geopotential heights (decametres, lines); $(\mathbf{B})$ precipitable water $(\mathrm{mm})$; $(\mathbf{C})$ Infrared $(10.8 \mu \mathrm{m})$ meteosat image, with an arrow indicating the front track path over Portugal; (D) convective precipitation rate ( $\mathrm{mm} /$ day). Sources: Reanalysis-2 data (A, B and D); Meteosat images archive, British Atmospheric Data Center (C).

Fig. 12 we can confirm that the 2006 events fall above those thresholds defined by the combination of the daily rainfall and the $C A R$ for $5,10,15$ and 30 days. The single exception to this rule corresponds to the 30 days $C A R$ for the 28 November event.

\section{Relationships with the North Atlantic Oscillation}

Recent works have been able to establish links between landslide activity and low frequency atmospheric circulation patterns such as the El Niño Southern Oscillation (ENSO) and the North Atlantic Oscillation (NAO). In particular Trigo et al. (2005) and Zêzere et al. (2005) have found a significant control exerted by NAO on the Portuguese mainland precipitation and over the recent geomorphological activity in the area around Lisbon. 
Table 4. Calibrated antecedent rainfall $(C A R)$ for periods of landslide activity in the Lisbon region during 2006.

\begin{tabular}{llllllll}
\hline & & \multicolumn{5}{c}{ Calibrated antecedent rainfall $(C A R)$} \\
\hline $\begin{array}{l}\text { Landslide } \\
\text { event }\end{array}$ & Date & $\begin{array}{l}\text { Daily } \\
\text { Rainfall } \\
(\mathrm{mm})\end{array}$ & $\begin{array}{l}5 \\
\text { days }\end{array}$ & $\begin{array}{l}10 \\
\text { days }\end{array}$ & $\begin{array}{l}15 \\
\text { days }\end{array}$ & $\begin{array}{l}30 \\
\text { days }\end{array}$ & $\begin{array}{l}\text { \# of previous consecu- } \\
\text { tive days with } 30-\text { days } \\
\text { daR }\end{array}$ \\
\hline 2006-A & $20-03-06$ & 42.1 & 89.6 & 89.7 & 95.9 & 107.4 & 2 \\
$2006-B$ & $27-10-06$ & 26.0 & 99.1 & 126.8 & 131.4 & 132.1 & 6 \\
$2006-C$ & $28-11-06$ & 36.5 & 58.0 & 62.8 & 74.5 & 79.6 & 3 \\
\hline
\end{tabular}

Table 5. Monthly values of the NAO index obtained from the Climatic Research Unit (CRU). The three months in 2006 characterised by landslides occurrence are highlighted in grey cells.

\begin{tabular}{lllllllllllll}
\hline & Jan & Feb & Mar & Apr & May & Jun & Jul & Aug & Sep & Oct & Nov & Dec \\
\hline 2005 & +1.82 & -2.25 & -1.29 & +0.71 & -0.13 & -1.00 & -0.08 & +0.94 & +0.50 & $\mathbf{- 0 . 4 5}$ & $\mathbf{- 1 . 0 1}$ & $\mathbf{- 0 . 8 1}$ \\
2006 & $\mathbf{- 1 . 2 4}$ & $\mathbf{- 0 . 1 0}$ & $\mathbf{- 1 . 1 2}$ & +0.57 & -0.22 & -0.41 & +0.83 & $\mathbf{- 2 . 4 7}$ & $\mathbf{- 1 . 0 2}$ & $\mathbf{- 1 . 9 7}$ & +1.70 & +3.08 \\
\hline
\end{tabular}

Having shown in previous works that the winter precipitation Iberia is largely associated with the NAO mode (Trigo et al., 2004, 2005) we will now concentrate on the precipitation that is measured at the rain gauge station located closer to the landslide events. For this purpose we use all the available monthly rainfall from November to March, at S. Julião Tojal, between 1939 and 2007. The inter-annual variability of this enlarged winter (NDJFM) precipitation and corresponding winter NAO index can be observed, for the 1932-2007 period in Fig. 13. It should be noticed that both curves (precipitation and NAO index) were normalized and the NAO index multiplied by minus one to facilitate visual comparisons. The correlation coefficient between both curves is $R=-0.65$ (statistically significant at the $1 \%$ level). This figure also puts into evidence that the vast majority of landslide events have occurred with higher than usual winter precipitation, and simultaneously with lower than average winter NAO index.

Finally we have analyse the role played by the NAO during (and prior to) those months of 2006 marked by landslide activity. Table 5 shows the monthly values of the NAO index available from the CRU website for the years 2005 and 2006, where we have highlighted in grey the three months of 2006 characterised by landslide activity in the Lisbon region. It should be noticed that prior to the March 2006 event, the winter of 2005-2006 was characterised by 5 consecutive months with $\mathrm{NAO}<0$, while the October (November) event was preceded by two (three) months with very low NAO values. Moreover, two of the months characterised by slope instability, namely March and October 2006, also present significantly negative NAO values. The only case where this is not observed corresponds to November 2006, where the observed positive monthly NAO value appears to contradict the general rule. In any case it should always be stressed that the three previous months (August-September-October)

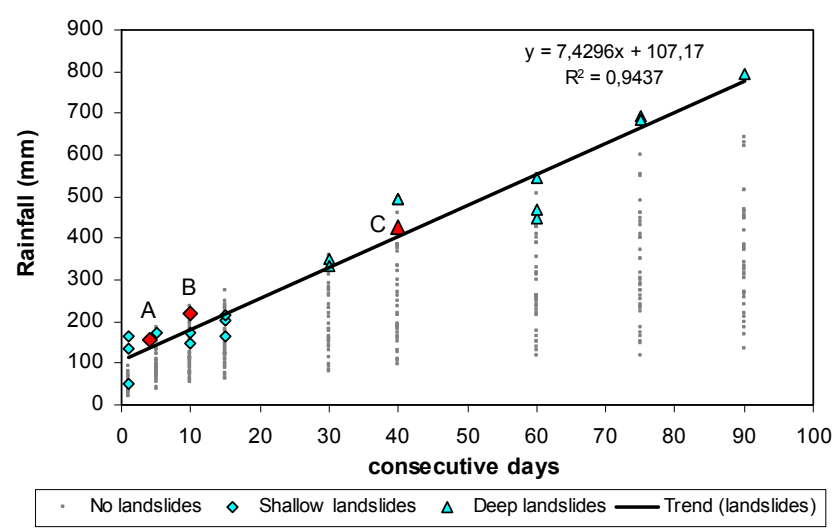

Fig. 10. Regression line between critical cumulative rainfall amount and corresponding rainfall event duration. Diamonds: values associated to shallow landslide events; Triangles: values associated to deep landslide events; Small grey dots: values obtained from the yearly cumulative rainfall values, and maximum rainfall intensity for all duration intervals (computed for years without reported landslides).Landslide events occurred in 2006 are marked in red: A - 20 March 2006; B - 27 October 2006; C - 28 November 2006.

were all characterised by negative NAO values and strong positive precipitation anomalies.

\section{Concluding remarks}

Landslides occurred during the last 5 decades in the Lisbon area were almost entirely triggered by precipitation, with shallow soil slips usually related to short intense rainfall periods (1-15 days) and deep slope movements mostly associated to longer periods of less intense rain (30-90 days). 
(a)
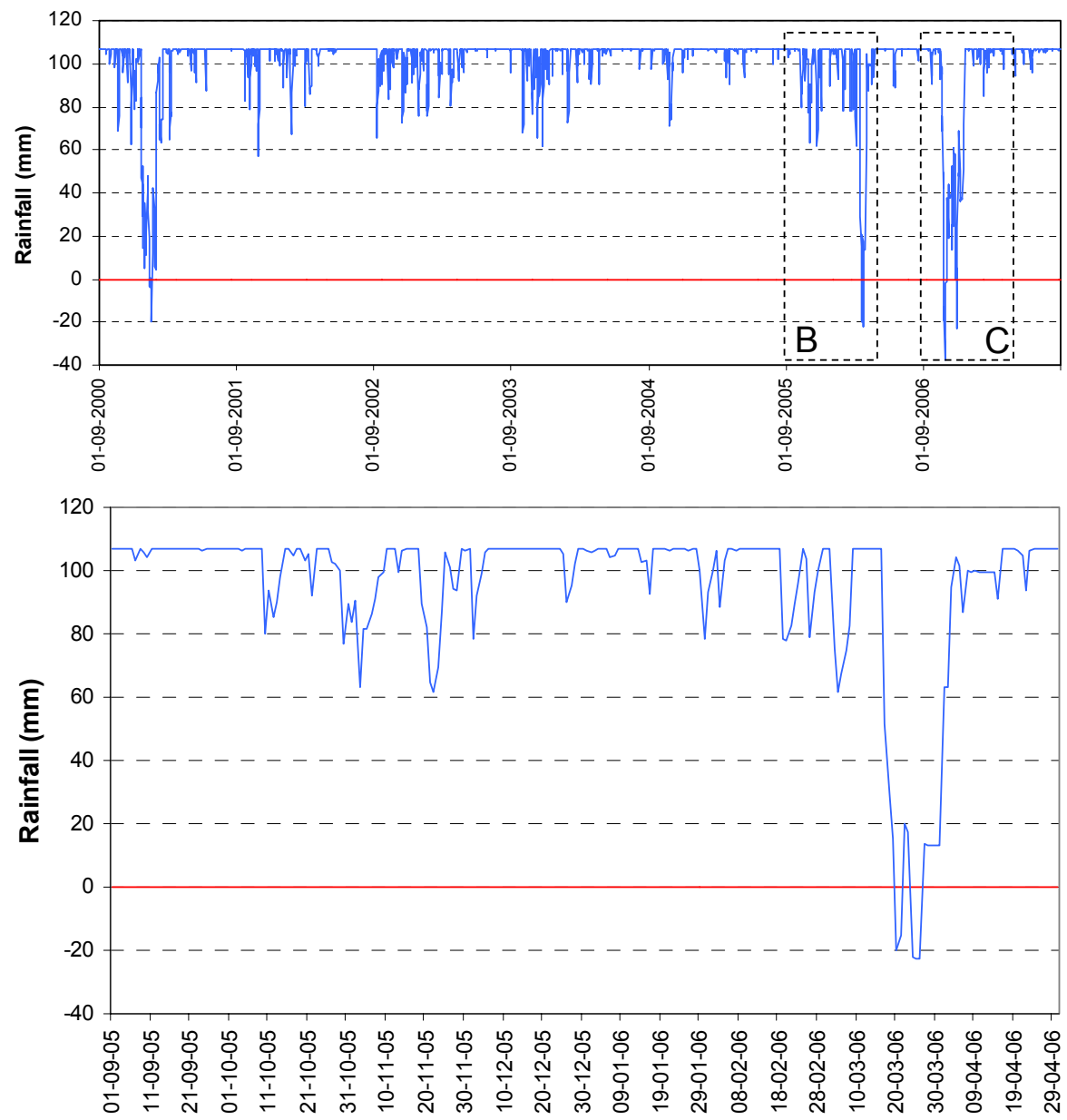

(b)

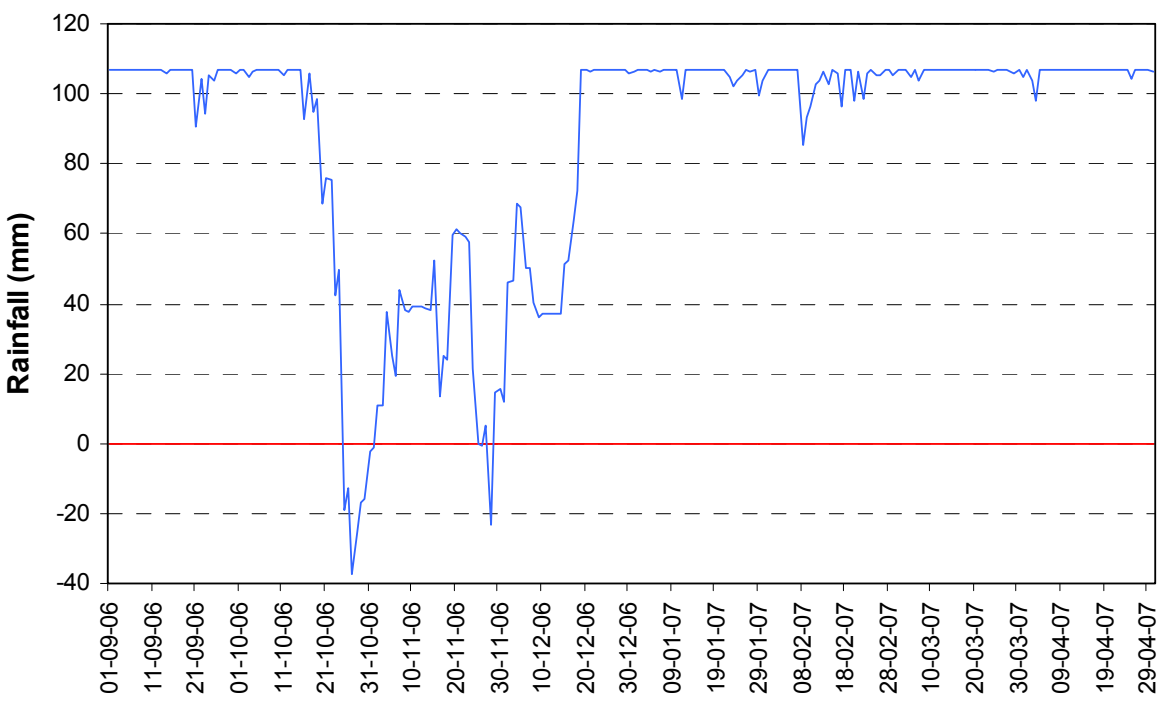

Fig. 11. Daily rainfall needed to reach the rainfall triggering threshold for any rainfall duration in S. Julião do Tojal. (a) data for the period September 2000-August 2007; (b) detailed data for the period September 2005-April 2006; (c) detailed data for the period September 2006-April 2007. 

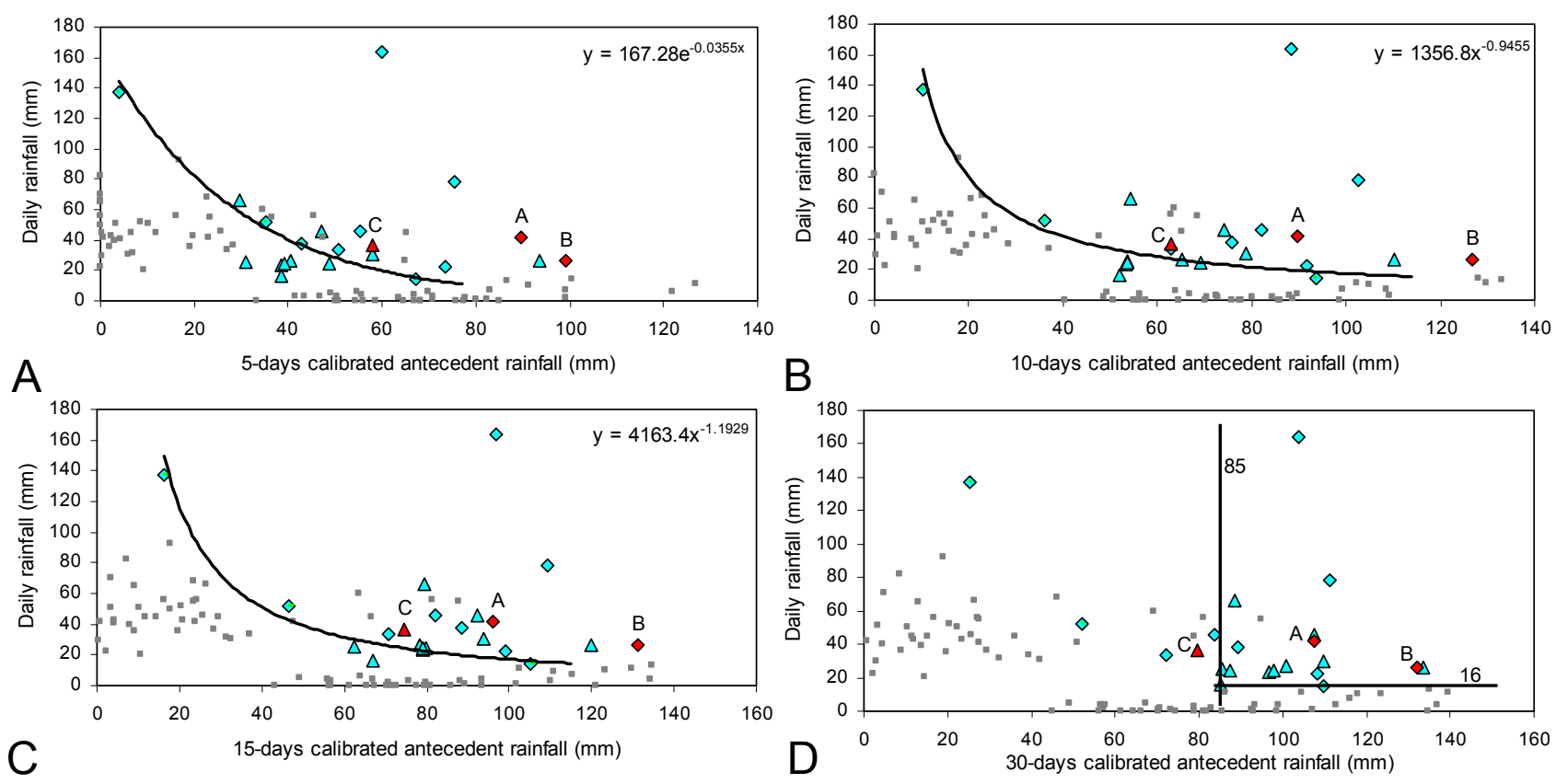

Fig. 12. Relationship between daily rainfall and calibrated antecedent rainfall (CAR) in 5 days (A), 10 days (B), 15 days $(\mathbf{C})$ and 30 days (D). Diamonds: values associated to shallow landslides occurrence; Triangles: values associated to deep landslides occurrence; Small grey dots: values obtained from the yearly maximum daily rainfall and from the yearly maximum $C A R$, computed for years without reported landslides; Landslide events occurred in 2006 are marked in red: A - 20 March 2006; B - 27 October 2006; C - 28 November 2006.

In 2006, three new rainfall-triggered landslide events occurred in the Lisbon region, namely on the 20 March, the 2527 October, and the 28 November. During these three events we have identified about 51 individual slope movements that spread over a geographical area larger than $1400 \mathrm{~km}^{2}$ (from Lisbon to the south flank of the Montejunto Mountain). These individual slope movements were characterised by different lithological, morphological and land cover conditions. The 20 March event comprises 21 individual landslides, essentially shallow slope movements ( $86 \%$ of total landslides), which concentrate mostly on the sedimentary formations of Upper Jurassic age (57\% of total registered landslides). The 25-27 October event includes 6 shallow soil slips, half of them occurred on basalts and volcanic tuffs belonging to the Upper Cretaceous Volcanic Complex of Lisbon. Finally, the 28 November 2006 event encompasses 24 individual landslides, including 7 rotational and 1 translational slides with deep slip surfaces. About half of these landslides concentrate on sandstones, conglomerates and clays of Upper Jurassic age.

The comparison between critical rainfall distribution and landslide incidence for the landslide events observed in 2006 led us to conclude that landslides have not clustered around those areas where the maximum rainfall was registered. Additionally, the spatial distribution of landslides, although influenced by the rainfall distribution, is controlled by the location of particular lithological units. Therefore, these results prove that excessive rainfall alone is not sufficient to trigger landslides on stable slopes, confirming the importance of the geological background as predisposing factor for slope instability. The landslide incidence observed in the Lisbon area in the last 50 years allows us to identify the Upper Cretaceous Volcanic Complex of Lisbon, the Albian-Cenomanian marls and clays, and the Upper Jurassic sandstones, conglomerates, marls, clays and limestones, as the most important landslideprone lithological units in the study area. From this perspective, the slope instability events verified in 2006 are found to be in accordance with this observation, because $78 \%$ of the total registered landslides concentrate within these lithological units.

The critical rainfall conditions responsible for each landslide event were assumed as the rainfall pair (amount - duration) characterised with the highest return period value. According to this criterion, the 20 March event was triggered by $155.8 \mathrm{~mm}$ of rain concentrated in 4 days, while the critical rainfall conditions for the 25-27 October event corresponded to $218.5 \mathrm{~mm}$ in 10 consecutive days. In contrast, the 28 November event was associated with a cumulative precipitation of $470 \mathrm{~mm}$ observed for the 40-days period. The March and October events were characterised by very intense rainfall ( 22 to $39 \mathrm{~mm} /$ day) that produced essentially shallow landslides (e.g. shallow translational slides and small debris flows). On the other hand, the November event was characterised by the long duration, but less intense precipitation 


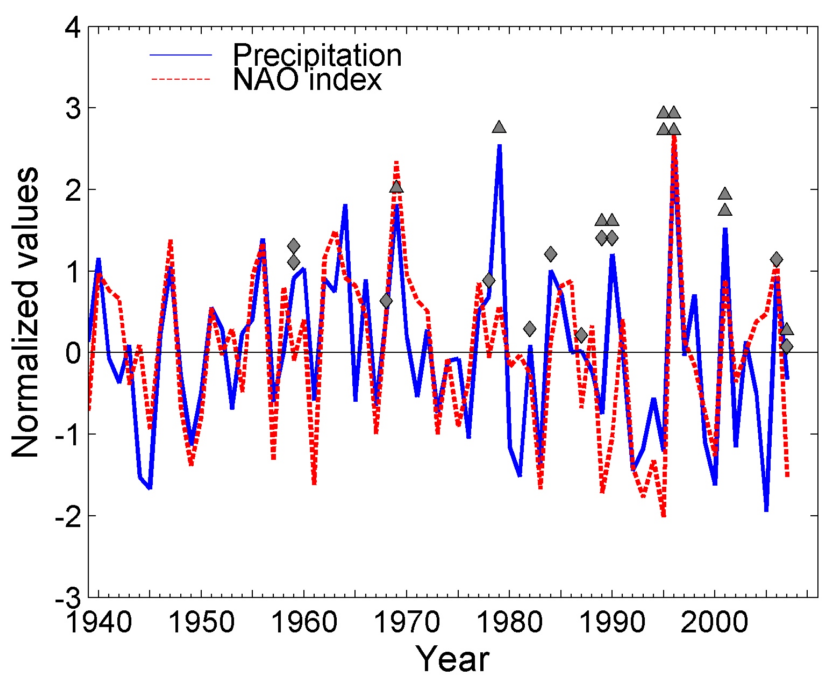

Fig. 13. Inter-annual variability of the mean winter (NDJFM) precipitation at S. Julião Tojal (solid curve), and the corresponding winter NAO index, multiplied by -1 to facilitate analysis (dashed curve); both curves have been normalised and so are dimensionless (period 1932-2007). Diamonds - events of shallow landslides activity; Triangles - events of deep landslides activity.

(11 mm/day), which produced some deep failures (e.g. rotational slides), associated to the steady rise of the groundwater table.

We have characterised in detail the short and long-term atmospheric circulation conditions that were responsible for the trigger of landslide events. It was shown that the three events correspond to considerably different synoptic atmospheric patterns, with the March event being associated to an intense cut-off low system and the October and November events related to more typical Atlantic low pressure systems (and respective fronts) travelling eastwards. It should be stressed that, different synoptic atmospheric patterns are able to generate relatively similar critical rainfall conditions (amount - duration) in the study area, therefore we did not find a unique connection between the synoptic atmospheric circulation and landslide activity.

Furthermore, we have analysed the role exerted by the North Atlantic Oscillation (NAO) during those months marked by landslide activity in order to establish possible relationships between this pattern of atmospheric circulation variability in the Northern Hemisphere and regional slope instability events. We have shown that the March event was preceded by 5 consecutive months with very low NAO values, while the October and November events were preceded, respectively, by 2 and 3 months with considerably negative values of NAO. Additionally, the NAO index was significantly negative during the months of the two first events (March and October 2006), and the single exception to this rule corresponds to November 2006. Nevertheless, despite the positive NAO value verified in November, this month was preceded by a long period (three months) with consistently NAO values below -1.0 . This result confirms what has been found by the authors on the pre-conditioned role played by consecutive months of negative NAO index (usually associated with positive precipitation anomalies) for a large number of landslide events in the study area (Trigo et al., 2005; Zêzere et al., 2005).

The critical rainfall values corresponding to landslide events occurred in 2006 were compared with the preestablished regression models regarding rainfall amount duration, in order to validate regional rainfall thresholds. It was found that landslide events verified in 2006 fall above the threshold corresponding to the regression model between the critical cumulative rainfall amount and the corresponding rainfall event duration for 19 landslide events occurred from 1956 to 2005 (i.e. $y=7.4 x+107$ ). Moreover, the reliability of this regression rule, as regional rainfall threshold, is confirmed by the inexistence of both "false positives" and "false negatives" during the period from January 2001 to March 2006.

We have proved that landslide events occurred in 2006 also fit regional thresholds defined by the combination of the daily rainfall and the calibrated antecedent rainfall $(C A R)$ for 5, 10, 15 and 30 days, although an exception to this rule was observed for the 30-days $C A R$ corresponding to the 28 November landslide event. This result may be explained by a limitation of the objective rule adopted, but it is possible that the exception is explained by the method used to derive the calibrated antecedent rainfall. In fact, the adoption of a constant $K=0.9$ might be a choice too drastic as it makes negligible all the rainfall that has occurred prior to 30 days before a landslide event. Therefore, as it stands, $C A R$ may not be the most suitable index to characterize landslide events associated to rainfall periods longer than 30 days, as was the case of the 28 November event.

We acknowledge that results obtained here need to be further confirmed in the near future, when further landslides events take place in the Lisbon area. In the meantime, we are confident that the validation exercise presented here is very promising for landslide risk mitigation purposes. In fact, the availability of daily rainfall records in near real time allows the automatic computation of the minimum daily rainfall needed to reach the precipitation triggering threshold, and therefore, the implementation of a regional landslide warning system.

Acknowledgements. This work was supported by the Portuguese Foundation for Science and Technology (FCT) through project Maprisk - Methodologies for assessing landslide hazard and risk applied to municipal planning (PTDC/GEO/68227/2006). R. M. Trigo was supported by the Portuguese Science Foundation (FCT) through project PREDATOR (Seasonal Predictability and Downscaling over the Atlantic European Region), Contract POCI/CTE-ATM/62475/2003. The research of R. A. C. Garcia and S. C. Oliveira was supported by the Portuguese Foundation for Science and Technology of the Portuguese Ministry of Science, 
Technology and Higher Education. The authors are thankful to R. Van Beek, D. Hantz and to an anonymous reviewer for their comments and suggestions that improved the quality of this paper.

Edited by: F. Catani

Reviewed by: D. Hantz, R. Van Beek, and another anonymous referee

\section{References}

Aleotti, P.: A warning system for rainfall-induced shallow failures, Eng. Geol., 73, 247-265, 2004.

Caine, N.: The rainfall intensity-duration control of shallow landslides and debris flows, Geogr. Ann., 62, 1-2, 23-27, 1980.

Corominas, J.: Landslides and climate, Keynote Lectures from the 8th International Symposium on Landslides, 4, 1-33, 2001.

Crozier, M.: Landslides: causes, consequences and environment, Croom Helm, London, 1986.

Daveau, S., Coelho, C., Costa, V. G., and Carvalho, L.: Répartition et rythme des précipitations au Portugal, Memórias do Centro de Estudos Geográficos, 3, Lisboa, 1977.

D’Orsi, R., D’Avila, C., Ortigão, J. A., Dias, A., Moraes. L., and Santos, M. D.: Rio-Watch: the Rio de Janeiro landslide watch system, Proc. 2nd PSL Pan-AM Symposium on Landslides, Rio de Janeiro, 1, 21-30, 1997.

Ferreira, D. B.: Carte Geomorphologique du Portugal, Memórias do Centro de Estudos Geográficos, Lisboa, 6, 1981.

Fukuoka, M.: Landslides associated with rainfall, Geotech. Eng., 11, 1-29, 1980.

Gimeno, L., Trigo, R. M., Ribera, P., and Garcia, J. A.: Editorial: Special issue on cut-off low systems (COL)", Meteorol. Atmos. Phys., 96, 1-2, doi:10.1007/s00703-006-0216-5, 2007.

Gostelow, P.: Rainfall and landslides, in: Prevention and control of landslides and other mass movements, edited by: AlmeidaTeixeira, M., Fantechi, R., Oliveira, R., and Gomes Coelho, A., CEC, Bruxels, 139-161, 1991.

Gumbel, E. J.: Statistics of extremes, Columbia University Press, New York, 1958.

Guzzetti, F., Peruccacci, S., Rossi, M., and Stark, C. P.: Rainfall thresholds for the initiation of landslides in central and southern Europe, Meteorol. Atmos. Phys., doi:10.1007/s00703-007-02627, 2007.

Iverson, R. M.: Landslide triggering by rain infiltration, Water Resour Res., 36, 1897-1910, 2000.

Keefer, D. K., Wilson, R. C., Mark, R. K., Brabb, E. E., Brown, W. M., Ellen, S. D., Harp, E. L., Wieczorek, G. F., Alger, C. S., and Zatkin, R. S.: Real-time landslide warning during heavy rainfall, Science, 238, 921-925, 1987.

Kulberg, M. C. and Kulberg, J. C.: Tectónica da região de Sintra.Tectónica das regiões de Sintra e Arrábida, Mem. Geociências, Museu Nac. Hist. Nat. Univ. Lisboa, 2, 1-34, 2000.
Nieto, R., Gimeno, L., De la Torre, L., Ribera, P., Barriopedro, D., García-Herrera, R., Serrano, A., Gordillo, A., Redaño, A., and Lorente, J.: Interannual variability of Cut-off-low systems over the European sector: The role of blocking and the Northern Hemisphere circulation modes, Meteorol. Atmos. Phys., 96, 85-101, 2007.

Paredes, D., Trigo, R. M., Garcia-Herrera, R., and Trigo, I. F.: Understanding precipitation changes in Iberia in early Spring: weather typing and storm-tracking approaches, J. Hidrometeorol., 7, 101-113, 2006.

Polemio, M. and Petrucci, O.: Rainfall as a landslide triggering factor: an overview of recent international research, in: Landslides in Research, Theory and Practice, edited by: Bromhead, E., Dixon, N., and Ibsen, M., London, Thomas Telford, 12191226, 2000.

Ribeiro, A., Antunes, M. T., Ferreira, M. P., Rocha, R. B., Soares, A. F., Zbyszewski, G., Almeida, F. M., Carvalho, D., and Monteiro, J.H.: Introduction à la géologie générale du Portugal, Serviços Geológicos de Portugal, Lisboa, 1979.

Trigo, R. M., Pozo-Vázquez, D., Osborn, T. J, Castro-Díez, Y., Gámiz-Fortis, S. and Esteban-Parra, M. J.: North Atlantic Oscillation influence on precipitation, river flow and water resources in the Iberian Peninsula, Int. J. Climatol., 24, 925-944, 2004.

Trigo, R. M., Zêzere, J. L., Rodrigues, M. L., and Trigo, I. F.: The influence of the North Atlantic Oscillation on rainfall triggering of landslides near Lisbon, Nat. Hazards, 36, 331-354, 2005.

Van Asch, T., Buma, J., and Van Beek, L.: A view on some hydrological triggering systems in landslides, Geomorphology, 30, 25-32, 1999.

Wieczorek, G. F.: Landslides triggering mechanisms, in: Landslides: Investigation and Mitigation, edited by: Turner, A. K. and Schuster, R. L., National Research Council, Transportation Research Board, Washington, 76-90, 1996.

Zêzere, J. L.: Rainfall triggering of landslides in the Area North of Lisbon, in: Landslides in Research, Theory and Practice, edited by: Bromhead, E., Dixon, N., and Ibsen, M., London, Thomas Telford, 3, 1629-1634, 2000.

Zêzere, J. L., Ferreira, A. B., and Rodrigues, M. L.: Landslides in the North of Lisbon Region (Portugal): Conditioning and Triggering factors, Phys. Chem. Earth, 24, 925-934, 1999.

Zêzere, J. L. and Rodrigues, M. L.: Rainfall Thresholds for Landsliding in Lisbon Area (Portugal), in: Landslides, edited by: Rybar, J., Stemberk, J., and Wagner, P., A. A. Balkema, Lisse, 333338, 2002.

Zêzere, J. L., Trigo, R. M., and Trigo, I. F.: Shallow and deep landslides induced by rainfall in the Lisbon region (Portugal): assessment of relationships with the North Atlantic Oscillation, Nat. Hazards Earth Syst. Sci., 5, 331-344, 2005, http://www.nat-hazards-earth-syst-sci.net/5/331/2005/. 